\title{
Uveitis as first manifestation of probably Crohn's disease
}

\author{
Uveíte como primeira manifestação \\ de provável doença de Crohn
}

leda Maria Alexandre Barreira', Ricardo Evangelista Marrocos de Aragão², Ariosto Bezerra Vale², Virgínia Apolônio Vieira ${ }^{4}$, Luanna Biana Costa Bezerra ${ }^{4}$

\begin{abstract}
Extraintestinal manifestations of Crohn's disease are common. Although ocular complications of Crohn's disease are infrequent, most ocular manifestations include iritis, uveitis, episcleritis, scleritis and conjuntivitis. We report a patient who developed uveitis two years before diagnose of Crohn's disease.

Keywords: Crohn disease/complications; Inflamatory bowel diseases/complications; Uveitis/etiology; Colitis, ulcerative; Optic disk ; Case reports
\end{abstract}

\section{RESUMO}

Manifestações extraintestinais da doença de Crohn são comuns. As manifestações oculares são infrequentes e caracterizam-se em sua maioria por irite, uveíte, episclerite, esclerite e conjuntivite. Relatamos o caso de uma paciente que desenvolveu uveíte dois anos antes de firmado o diagnóstico de doenca de Crohn.

Descritores: Doença de Crohn/complicações; Doenças inflamatórias intestinais/complicações; Uveíte/etiologia; Colite ulcerativa; Disco óptico ; Relatos de casos

${ }^{1}$ Hospital de Olhos de Iguatu - Igatu (CE), Brazil;

${ }^{2}$ Hospital Universitário Walter Cantídio Universidade Federal do Ceará (UFC) - Fortaleza (CE), Brazil;

${ }^{3}$ Programa de Residência do Serviço de Oftalmologia do Hospital Universitário Walter Cantídio, Universidade Federal do Ceará (UFC) Fortaleza (CE), Brazil;

${ }^{4}$ Programa de Residência do Serviço de Oftalmologia do Hospital Universitário Walter Cantídio, Universidade Federal do Ceará (UFC) -

Fortaleza (CE), Brazil.

Study carried out at Universidade Federal do Ceará (UFC) - Fortaleza (CE), Brazil.

The authors declare no conflicts of interest

Recebido para publicação em: 4/4/2011 - Aceito para publicação em: 13/2/2012 


\section{INTRODUCTION}

C rohn's disease (CD) is a sistemyc inflammatory disease which primarily involves the intestine but pontecially affect many organs such as the kidney and eye. ${ }^{(1)}$ The eye is involved in 4 to $6 \%$ of patients and a wide spectrum of conditions may occur. The ocular involvement may occur before or after the bowel symptoms anterior segment changes such as episcleritis, scleritis, keratitis and iridocyclitis are the commom eye manifestations ${ }^{(2)}$. Optic disc swelling and other posterior segment manifestations are $\operatorname{rare}^{(3)}$. Other manifestations as chroidal infiltrates, cystoid macular edema and serous macular detachment has been less frequently documented ${ }^{(2)}$. We describe a case with $\mathrm{CD}$ and panuveites, optic disc swelling, chroidal infiltrates and glaucoma.

\section{Case Report}

A 29-year-old white woman presented with ocular pain in the right eye for two days. On examination, the best correct visual acuity (BCVA) was found to be: right eye (OD) 20/25, left eye (OS) 20/20, fundoscopy revealed optic disc swelling and afferent pupillary defect in OD. The anterior segments were normal with no evidence of intraocular inflamation in both eyes (OU). The perimetry in the OD revealed a paracentral scotoma. Neurological examination and magnetic resonance imaging (MRI) was otherwise non-contributory. One week later the fundoscopy revealed macular star (Figure 1). Sorological examination were negative for syphilis, toxoplasmose, bartonella hanselae and tuberculin skin test were also negative. Urinary, and completed serum blood examitation was normal.

Three weeks later the patient presented with anterior chamber cels $2+$, haze $1+$ keratic precipitates, vitritis $2+$, intra-ocular pressure $48 \mathrm{mmHg}$, choroidal infiltrates and BCVA 20/40 in OD (Figure 2). Biochemical, infectious and rheumatic screens were negative. The patient was treated with prednisolone sodium phosphate $0.5 \%$, atropine $1 \%$, timolol $0.5 \%$, brimonidine, brinzolamide eye drops. The intraocular inflamation and visual acuity has improved OD 20/25. After three months the intra-ocular inflamation recurred. At this time the patient was treated with topical and sistemic steroides with improvement. Completed infection, serum examination was repeted and reveled negative. Patient followed with intraocular inflation intermittently.

After two years, she developed arthitis and perianal fistula, when she was diagnostic with Crohn's disease which was cofirmed by colonoscopy and biopsy.

Treatment wih infliximab was instituted with improvement of bowel and joint symptoms controled of the intra-ocular inflamation.

\section{Discussion}

Ophthalmic complications of IBD (inflamatory bowel diseases) have been reconigzed ever since the first description of two patient with conjuntivitis and corneal infiltrates resembling «xerophthalmia » by Crohn in $1925^{(4,5)}$.

Several possible machanism for the ocular involvement in Crohn's disease have been sugested. Among them are hypersensitivity reaction based on autoimmune mechanism and a greater incidence of throboembolic phenomena. No absolut correlation has been shown to exist between the severity of the systemic disease and the appearence of the ocular manifestations $^{(6)}$.

Different incidence rate of ocular complications of IBD are reported in the literature. A recent study reported that the incidence of ocular involviment was $4-10 \%$ in $\mathrm{CD}$ and $8 \%$ in ulcerative colitis ${ }^{(4)}$. Uveitis is the main ocular manifestation of the $\operatorname{IBD}^{(7,8)}$. Common ocular features in $\mathrm{CD}$ include include anterior uveitis, episcleritis and more rarely scleritis, keratitis, orbital pseudotumour and retinal vasculitis which may cause retinal artery occlusion ${ }^{(8)}$. Chroidal infiltrates, optic neuritis, cystoid macular edema and serous macular detachment has been less frequently documented ${ }^{(2)}$.

In this report our patient has an onset with disc swelling, anterior chamber reaction and chroidal infiltrates two years before the sistemic manifstations of $\mathrm{CD}$. This ressalts the dificult to diagnose in some cases of the uveitis and the importance of good follow-up with the ophthalmologist and a multidisciplinar team.

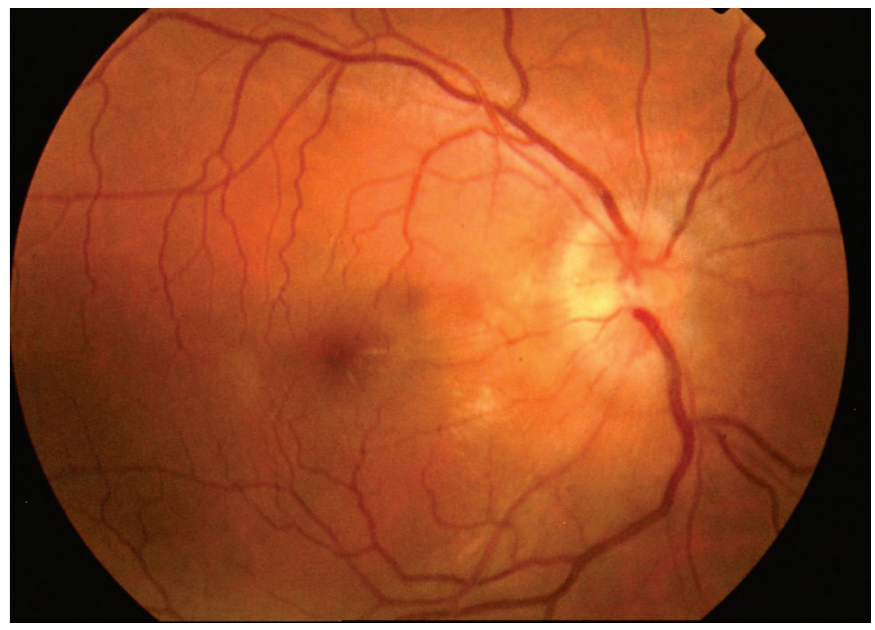

Figure 1: Right eye with disc swelling and macular star

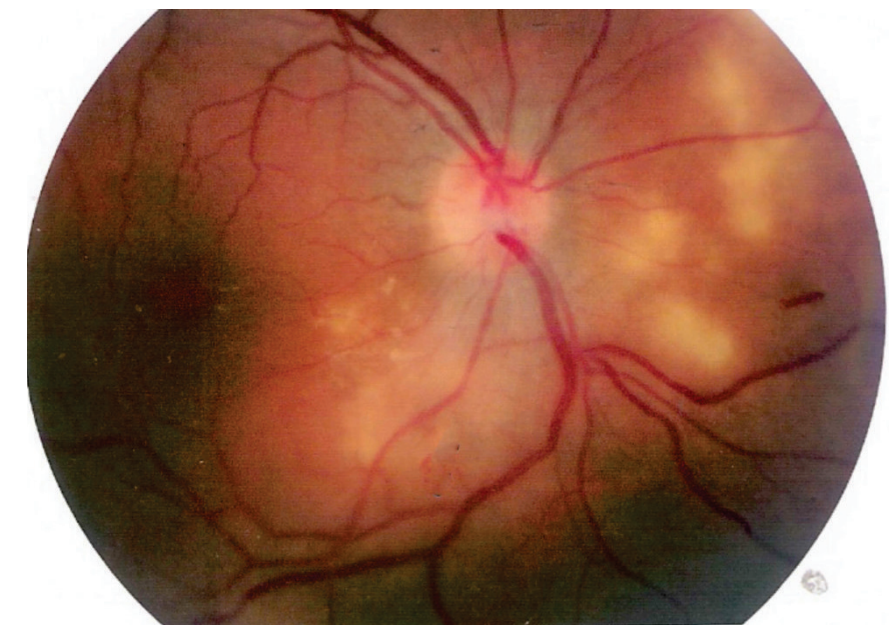

Figure 2: Right eye with choroidal infiltrates 


\section{ReFERENCES}

1. Unal A, Sipahioglu MH, Akgun H, Yurci A, Tokgoz B, Erkilic K, et al. Crohn's disease complicated by granulomatous interstitial nephritis, choroidal neovascularization, and central retinal vein occlusion. Intern Med. 2008;47(2):103-7.

2. Saatci OA, Koçak N, Durak I, Ergin MH. Unilateral retinal vasculitis, branch retinal artery occlusion and subsequent retinal neovascularization in Crohn's disease. Int Ophthalmol. 2001;24(2): 89-92.

3. Walker JC, Selva D, Pietris G, Crompton JL. Optic disc swelling in Crohn's disease. Aust N Z J Ophthalmol. 1998;26(4):329-32. Erratum in Aust N Z J Ophthalmol. 1999;27(2):161.

4. Yilmaz S, Aydemir E, Maden A, Unsal B. The prevalence of ocular involvement in patients with inflammatory bowel disease. Int $\mathbf{J}$ Colorectal Dis. 2007;22(9):1027-30.

5. Hopkins DJ, Horan E, Burton IL, Clamp SE, de Dombal FT, Goligher JC. Ocular disorders in a series of 332 patients with Crohn's disease. Br J Ophthalmol. 1974;58(8):732-7.
6. Yassur Y, Snir M, Melamed S, Ben-Sira I. Bilateral maculopathy simulating 'cherry-red spot' in a patient with Crohn's disease. Br J Ophthalmol. 1981;65(3):184-8.

7. Chaoui Z, Bernoussi A, Belmekki M, Berraho A. Uvéites et maladies inflammatoires chroniques de l'intestin: à propos de 3 cas. J Fr Ophtalmol. 2005;28(8):854-6.

8. Soomro H, Armstrong M, Graham EM, Stanford MR. Sudden loss of vision caused by a vasculitic ophthalmic artery occlusion in a patient with ankylosing spondylitis and Crohn's disease. Br J Ophthalmol. 2006;90(11):1438.

\section{Autor correspondente:}

Ricardo Evangelista Marrocos de Aragão

Rua Osvaldo Cruz, 2335

CEP 60125-151- Dionísio Torres - Fortaleza (CE), Brasil

E-mail: ricardomarrocos@yahoo.com 